EGALITA, Jurnal Kesetaraan dan Keadilan Gender, Pusat Studi Gender (PSG) Universitas Islam Negeri Maulana Malik Ibrahim Malang. Copyright @ 2009. Vol. IV Nomor 2 Tahun 2009 : 199 - 206

\title{
Perempuan dan Kesehatan Reproduksi
}

\author{
Imamah \\ Mahasiswa Jurusan Matematika Program Pascasarjana ITS Surabaya \\ Telepon: 08597654078 \\ Email:imamah@mhs.matematika.its.ac.id
}

\begin{abstract}
Abstrak
In terms of Indonesian women's health services are still treated unfairly and still are the number two. It can be seen from the report reporting Indonesia Human Development Report 2005 on maternal mortality rate (MMR) delivery, which is currently listed at number 307 out of every 100,000 live births. This shows that the government has not seriously and equitable in the provision of health services particularly for women. Maternal mortality can be used as indicators of poor health services received by mothers and children and low access to information owned by mother and child.
\end{abstract}

Dari segi pelayanan kesehatan perempuan Indonesia masih diperlakukan tidak adil dan masih merupakan masyarakat nomor dua. Hal ini dapat dilihat dari laporan laporan Indonesia Human Development Report 2005 tentang angka kematian ibu (AKI) melahirkan, yang saat ini tercatat berada di angka 307 dari setiap 100.000 kelahiran hidup. Hal ini menunjukkan bahwa pemerintah belum serius dan merata dalam pemberian pelayanan kesehatan khususnya bagi perempuan. Angka kematian ibu ini dapat dijadikan indikator rendahnya pelayanan kesehatan yang diterima ibu dan anak serta rendahnya akses informasi yang dimiliki ibu dan anak.

Keywords: Perempuan, Human Development Report, Angka Kematian 
Ibu, Indikator dan Kesehatan.

\section{Pendahuluan}

Kesehatan reproduksi adalah suatu kondisi yang sempurna dari fisik, mental dan keadaan sosial (tidak hanya bebas dari penyakit atau kelemahan/ kecacatan) dalam setiap persoalan yang berhubungan dengan sistem, fungsi serta proses reproduksi. Konsep dan definisi lainnya yang juga disepakati dan berkaitan dengan kesehatan reproduksi, yaitu kesehatan seksual, hak seksual, dan hak reproduksi.

Sejak tahun 2000, kesehatan reproduksi merupakan salah satu topik penting yang mendapat perhatian dari berbagai pihak, baik di dalam maupun di luar negeri. Meluasnya liputan media massa sampai ke pelosok negeri yang menyajikan fakta seputar kesehatan reproduksi, baik positif maupun negatif mendorong pemerintah, perorangan, swasta dan lembaga swadaya masyarakat untuk mengambil peran aktif dalam menyosialisasikan sekaligus memberikan jalan keluar atas permasalahan kesehatan reproduksi.

Angka kematian ibu (maternal mortality rate/MMR) di Indonesia sebesar 228 per 100.000 kelahiran hidup (SDKI, 2007) walaupun lebih rendah dibandingkan dengan angka IMR sebelumnya, yakni 307 per 100.000 kelahiran hidup (SDKI, 2002-2003), masih termasuk ke dalam kategori tinggi di antara negara-negara di Asia Selatan dan Pasifik. Faktor penyebab yang tertinggi adalah perdarahan, di samping faktor sosial budaya dan non-kesehatan lainnya. Fakta ini diikuti oleh tingginya angka kematian bayi (infant mortality rate/IMR) dengan angka 34 per 1000 kelahiran hidup (SDKI, 2007) serta aborsi akibat kehamilan yang tidak diinginkan (KTD) di kalangan remaja (Susilowati, N., 2008).

Hasil laporan Indonesia Human Development Report 2005 tentang angka kematian ibu (AKI) melahirkan, yang saat ini tercatat berada di angka 307 dari setiap 100.000 kelahiran hidup, sebagian besar adalah kematian yang sebetulnya dapat dihindari. AKI ini menjadi indikator dari tingkat pembangunan manusia suatu bangsa. Hal ini menunjukkan bahwa pemerintah belum serius dan merata dalam pemberian pelayanan kesehatan khususnya bagi perempuan. Angka kematian ibu ini dapat dijadikan indikator rendahnya pelayanan kesehatan yang diterima ibu dan anak serta rendahnya akses informasi yang dimiliki ibu dan anak.

Survei Kesehatan Rumah Tangga (SKRT) tahun 1995 juga mendapatkan 
data AKI di Indonesia adalah 373 per 100.000 kelahiran hidup. Diantara penyebab kematian ibu tersebut diantaranya anemia, kurang gizi, perdarahan karena aborsi, dan lain-lain. Data WHO memperkirakan 10-50 persen AKI disebabkan aborsi. Berarti, dari setiap seratus ribu kelahiran hidup sekitar 37 sampai 186 perempuan diantaranya meninggal sia-sia akibat komplikasi pengguguran kehamilan .

Fakta mengenai aborsi akhir-akhir ini menunjukkan jumlah yang cukup mengagetkan. Budi Utomo dan kawan-kawan (2002) dalam penelitiannya di 10 kota besar dan 6 kabupaten, menemukan bahwa pertahun terdapat 2 juta kasus aborsi, atau 37 aborsi per 1000 perempuan usia 15-49 tahun, atau 43 aborsi per 100 kelahiran hidup, atau 30\% kehamilan. WHO memperkirakan, di Asia Tenggara 4,2 juta aborsi dilakukan setiap tahunnya dan Indonesia berkontribusi sekitar 750.000 sampai 1.500 .000 kasus. Dari jumlah tersebut 2.500 di antaranya berakhir dengan kematian (Siswono, 2005).

Dari sisi perbandingan jumlah aborsi di kota dan desa hampir sama. Kasus aborsi di perkotaan dilakukan secara diam-diam oleh tenaga kesehatan, sebanyak $73 \%$. Sedangkan di pedesaan sebagian besar dilakukan secara diam-diam oleh dukun, sebanyak $84 \%$. Aborsi yang dilakukan secara diamdiam inilah yang menempatkan perempuan harus menanggung resiko tidak adanya perlindungan pemerintah cq Departemen Kesehatan, termasuk bila terjadi kematian karena komplikasi perdarahan dan infeksi.

Faktor-faktor penentu yang mempengaruhi aborsi terdapat pada level individu, keluarga/masyarakat dan negara. Ketiga level tersebut memiliki keterkaitan satu sama lain yang tidak dapat dipisahkan. Pengaruh dari ketiga level tersebut berdampak pada banyaknya praktek aborsi tidak aman (unsafe abortion) yang mengakibatkan pada tingginya AKI di Indonesia. Selama aborsi dianggap bertentangan dengan hukum, maka tidak mungkin diatur pelayanan aborsi yang aman. Selama tidak ada aturan mengenai pelayanan aborsi yang aman, maka akan terus terjadi praktek aborsi secara diam-diam dan cenderung tidak aman karena dilakukan tanpa prosedur maupun standar operasional kesehatan yang jelas yang dapat dijadikan sebagai pedoman.

Dari sudut pandang moralitas, aborsi dan kematian ibu keduanya dipermasalahkan karena sama-sama mengancam kelangsungan hidup janin dan ibu. Namun, perlu didudukkan dalam proporsinya masing-masing, manakah pilihan yang lebih bermanfaat dan maslahat dalam menyelesaikan problem kesehatan reproduksi ini. Aborsi tidak harus mengorbankan kehidupan insani bila masih dalam taraf kehidupan sel (hayati). Tetapi 


\section{Imamah}

membiarkan praktek aborsi tidak aman lebih berbahaya karena membiarkan nyawa perempuan yang jelas-jelas telah hidup secara insaniyah (sebagai manusia) dan memiliki tanggung jawab pada orang lain dikorbankan.

\section{Pembahasan}

Dalam keadaan negara yang mengalami krisis multidimensi, perempuan yang menanggung beban terberat dalam keluarganya. Keragaman perempuan berdasarkan kelas, ras, maupun nasional, dikaitkan dalam benang merah isu-isu sentral perempuan seperti pendidikan, kesehatan reproduksi, kerja domestik, upah rendah, peran ganda, kekerasan seksual, ideologi gender, terutama pada masyarakat yang telah mengenal kapitalisme dan komersialisasi.

Tingginya angka aborsi tidak aman di Indonesia yang diikuti dengan tingginya resiko kematian ibu hendaknya tidak dilihat sebagai sesuatu yang berdiri sendiri, tetapi dikarenakan berbagai faktor penentu baik di level individu, keluarga atau masyarakat maupun negara. Faktor penentu pada level individu antara lain karena kegagalan alat kontrasepsi, masalah kesehatan, psikologis, ekonomi dan ketidak tahuan cara pencegahan kehamilan dengan benar. Pada level keluarga dan masyarakat, faktor penentunya antara lain karena kemiskinan, pengetahuan anggota keluarga termasuk suami yang rendah, pandangan agama yang sempit, tidak mampu mengakses pelayanan aborsi yang aman dan stigma takut dan malu jika diketahui orang lain. Sementara faktor penentu pada level negara adalah adanya larangan aborsi dengan alasan apapun di Indonesia, sebagaimana dinyatakan dalam Kitab Undang-Undang Hukum Pidana (KUHP) pasal 346349 dan Undang-Undang Kesehatan nomor 23/1992 pasal 15 ayat 1 dan 2.

Melihat kenyataan lambatnya penurunan besaran AKI yang dapat dianggap sebagai salah satu petunjuk kurangnya komitmen pemerintah terhadap kesejahteraan perempuan, salah satu harapan yang dapat menurunkan dengan cepat AKI dan meningkatkan secara nyata kesejahteraan perempuan adalah amandemen Undang-Undang Nomor 23 Tahun 1992 tentang Kesehatan.

Dampak dari masalah reproduksi kesehatan ini berkaitan langsung dengan penduduk miskin. Perempuan miskin lebih banyak memiliki anak yang tidak diinginkan karena kurang mendapatkan akses terhadap pelayanan dan informasi kesehatan reproduksi. Kemungkinan terkena infeksi menular seksual, termasuk HIVIAIDS, menambah risiko yang akan dihadapi oleh 
perempuan; ketidakadilan gender sering menghilangkan kemampuan perempuan untuk menolak praktek-praktek berisiko kekerasan seksual dan perilaku seksual, membuat perempuan tidak mendapat informasi mengenai pencegahan dan menempatkan mereka di urutan terakhir dalam pelayanan dan tindakan untuk menyelamatkan kehidupan.

Dalam kebijakannya khususnya tentang kesehatan reproduksi perempuan pemerintah masih belum adil dan menjadikan perempuan sebagai target utama dari kebijakan dalam bidang kesehatan dan kependudukan yang selama ini dilakukan pemerintah. Selama ini perempuan ditempatkan hanya sebagai instrumen perantara dalam mencapai target kependudukan atau kesehatan yang dicanangkan pemerintah tanpa memandang hak-hak perempuan atas tubuhnya sendiri.

Sebagai contoh kebijakan pemerintah dalam program keluarga berencana (KB). Program KB selama ini mengarahkan sasaran pada perempuan, sebagian masyarakat masih menganggap KB dan kesehatan reproduksi serta kesehatan ibu dan anak merupakan urusan perempuan dimana keputusan untuk ber-KB, pergi periksa kehamilan, imunisasi bayi diserahkan pada kaum perempuan/ibu.

Selain itu dalam kebijakan program KB ini pemerintah juga membatasi akses perempuan terhadap manfaat dan resiko dari metoda KB seperti IUD dan metoda hormonal. Cara seperti ini merupakan intervensi panjang terhadap kesehatan reproduksi/alat reproduksi perempuan (selama beberapa tahun atau bulan) sedangkan perempuan berpeluang untuk hamil hanya selama beberapa jam dalam setiap siklus haid. Selain itu beberapa resiko kesehatan atau efek samping yang akan dihadapi perempuan terkait dengan pemakaian alat kontrasepsi tersebut seperti tekanan darah tinggi, ketidakteraturan haid, pendarahan, sakit kepala, tidak banyak dibicarakan pemerintah.

Dari data pada tabel dibawah ini terlihat bahwa pemakaian alat kontrasepsi lebih didominasi perempuan dibandingkan lakilaki. Hal ini terlihat dari persentase penggunaan kontrasepsi di Indonesia tahun 1994/1995 sebagai berikut :

\begin{tabular}{|l|r|}
\hline \multicolumn{1}{|c|}{ Alat Kontrasepsi } & \multicolumn{1}{c|}{ Persentase } \\
\hline Pil & $31,4 \%$ \\
\hline Suntik & $30,9 \%$ \\
\hline IUD & $22,2 \%$ \\
\hline
\end{tabular}




\begin{tabular}{|l|r|}
\hline Implant/Norplant & $8,0 \%$ \\
\hline Tubektomi & $4,5 \%$ \\
\hline Kondom & $1,6 \%$ \\
\hline Vasektomi & $1,4 \%$ \\
\hline
\end{tabular}

Dari data diatas, dapat dilihat bahwa hanya 3\% dari alat kontrasepsi yang ditujukan kepada laki-laki, sementara $97 \%$ ditujukan kepada perempuan. Sehingga diperlukan upaya nyata pemerintah dalam meningkatkan angka parti-sipasi pria dalam program KB ini. Karena laki-laki mempunyai hak-hak kesehatan reproduksi yang sama dengan perempuan/isteri

Menurut estimasi WHO , sampai dengan Juni 2000 terdapat sekitar 34,3 juta orang dewasa dan anak mengidap HIVIAIDS dan lebih dari 18 juta yang meninggal. Ternyata 95\% dari jumlah tersebut berada di negara berkembang, 52000 kasus terjadi di Indonesia. Dari kasus HIVIAIDS di Indonesia tersebut, 70 persen adalah ibu rumah tangga yang menjadi korban tidak langsung dari penyebaran HIV ini (laki-laki sebagai penyebar potensial tertinggi). Hal terjadi karena infeksi HIV diseluruh dunia terjadi melalui hubungan seks antara laki-laki dan perempuan. Dan hampir $80 \%$ perempuan yang mengidap HIVIAIDS hanya berhubungan dengan satu pria, suaminya.

Dari permasalahan di atas maka perlu dilakukan perubahan dan pende-katan dalam menangani masalah kebijakan dalam bidang kesehatan reproduksi ini diantaranya :

1. Peningkatan kondisi kesehatan perempuan dan peningkatan kesempatan kerja

Hal ini dilakukan dalam upaya untuk meningkatkan usia kawin dan melahirkan, sehingga resiko selama kehamilan akan menurun.

2. Pendekatan target pada program KB harus disertai dengan adanya tenaga dan peralatan medis yang cukup. Hal ini untuk mencegah terjadinya malpraktek karena keinginan untuk mencapai target.

3. Peningkatan partisipasi laki-laki dalam menurunkan angka kelahiran. Tidak hanya perempuan yang dituntut untuk mencegah kehamilan, tetapi juga laki-laki, karena pada saat ini sudah tersedia beberapa alat kontrasepsi untuk laki-laki. Penyadaran akan kesetaraan dalam menentukan hubungan seksual dengan laki-laki. Penyadaran bahwa perempuan berhak menolak berhubungan seksual dengan laki-laki, meskipun laki-laki tersebut suaminya, bila hal itu membahayakan kesehatan reproduksinya (misalnya laki-laki 
tersebut mengidap HIVIAIDS).

4. Penyuluhan tentang jenis, guna, dan resiko penggunaan alat kontrasepsi Baik alat kontrasepsi modern maupun tradisional perlu diperkenalkan guna dan resikonya kepada perempuan. Dengan demikian perempuan dapat menentukan alat kontrasepsi mana yang terbaik untuk dirinya.

5. Penyuluhan tentang HIVIAIDS dan PMS (penyakit menular seksual) kepada perempuan.

6. Pendidikan seks pada remaja perempuan dan laki-laki.

Kebijakan kesehatan yang menghormati hak perempuan atas tubuhnya, dalam jangka panjang akan memberikan kontribusi yang nyata dalam mengatasi masalah kependudukan, dengan resiko yang jauh lebih kecil dibanding kebijakan kependudukan menggunakan kontrasepsi modern.

Islam memandang laki-laki dan perempuan adalah dua makhluk yang setara. Dijelaskan dalam QS. Al-Hujurat ayat 13 bahwa antara laki-laki dan perempuan memiliki kesetaraan potensi untuk mencapai status tertinggi di hadapan Tuhan. Dalam QS. Al-Ghafir ayat 40, Tuhan juga memberikan penghargaan yang sama antara karya positif laki-laki dan karya positif yang dihasilkan perempuan, dengan harga yang sama. Al-Qur'an memang mengungkapkan perbedaan mendasar antara laki-laki dan perempuan, tetapi harus dicermati kembali apakah ungkapan tersebut mengacu kepada unsur biologis atau non-biologis (Sumbulah, 2006: 37)

\section{Kesimpulan}

Kesehatan reproduksi adalah suatu kondisi yang sempurna dari fisik, mental dan keadaan sosial dari manusia. Oleh karena itu pemerintah sebagai perumus dan pemilik kebijakan khususnya tentang kesehatan reproduksi perempuan harus lebih adil dan menghormati hak perempuan atas tubuhnya, sehingga dalam jangka panjang akan memberi-kan kontribusi yang nyata dalam mengatasi masalah kependudukan dengan resiko yang jauh lebih kecil dibanding kebijakan kependudukan menggunakan kontrasepsi modern. 


\section{DAFTAR PUSTAKA}

Anonemous, Bias Gender dalam Kebijakan Kesehatan Reproduksi di Indonesia. www.duniaesai.com (Diakses 10 Maret 2010)

Biro Pusat Statistik. 1995. Statistik Kesejahteraan Rakyat 1994.

DepKes RI-Pusdakes, 1998. Profil Kesehatan Indonesia 1998, Jakarta: Depkes RI, Pusat Data Kesehatan.

Maria, U.A. 2007. Penguatan Hak Kesehatan Reproduksi Dalam Komunitas Islam. Laporan LK2P Fatayat NU, Tangerang.

Siswono, 2005. Hari Kartini, Kesehatan Reproduksi Perempuan, dan Amandemen UU Kesehatan. http://www.kompas.co.id, (Diakses 10 Maret 2010)

Susanti, Z dan kartika, H. 2004. Masalah Gender dan Kesehatan. Pusat Penelelitian Ekologi Kesehatan, Badan Penelitian dan Pengembangan Kesehatan, Departemen Kesehatan RI, Jakarta. Jurnal Cermin Dunia Kedokteran No. 145, 2004:43.

Susilowati, N. 2008. Gender dalam Kesehatan Reproduksi, Pusat Pelatihan Gender dan Peningkatan Kualitas Perempuan, Jakarta: BKKBN Pusat

Sumbulah, U. 2006. Buku Gender dan Islam. UIN Press, Malang.

Utomo, Budi dkk, 2002. Angka Aborsi dan Aspek Psiko-Sosial di Indonesia: Studi di 10 Kota Besar dan 6 Kabupaten. Jakarta: Pusat Penelitian Kesehatan Universitas Indonesia.

WHO dalam Gulardi H Wignyosastro, 2001. Masalah Kesehatan Perempuan Akibat Reproduksi, Makalah seminar Penguatan HakHak Reproduksi, diselenggarakan oleh Fatayat NU, Jakarta 1 September 2001. 